\title{
INFLUENCE OF INNOVATION FACTOR IN ECONOMIC DYNAMICS IN EUROPE
}

In the article evaluated the relationship of indicators of innovation and economic development in Europe. A high level of dependence between index innovation and terms of GDP per capita (PPP). Established most significant factors affecting the level of economic development of the innovation analyzed for a set of European countries in general and Ukraine in particular.

Keywords: innovations, innovative development, economic growth, European countries, rating correlation connection.

DOI: $10.21272 / \mathrm{mmi} .2018 .1-18$

Formulation of the problem in general form. Trends in the economy in the era of globalization formed the decline in the importance of material factors of production and transformation of intellectual resources in the main resource of becoming a postindustrial society. The main features of the knowledge economy is its focus on innovative development model, the materialization of knowledge into new products, obtaining new scientific results and their manufacturing, the growing share of high technology products in the created value.

The level of development of science, technology determines the position of countries in the global economy determines the size of the gap between the levels of economic development and forms the basis for sustainable economic growth. The innovative factor as productive characteristics of intellectualization of social production largely determines the quantitative parameters of economic growth creates the preconditions for modernization and improving the efficiency of the national economy. Considerably influences innovation processes on economic mechanisms to study the relationship actualizes determinants that determine the degree of innovation economic development, and the most important macroeconomic indicators.

Analysis of recent research and publication. The problem of formation and use of innovative capacity as a factor of economic growth has always actively considered by the scientific community. Significant role of innovation in ensuring high economic growth and social development of virtually all recognized scholars. The question of decisive influence scientific and technological progress and innovation processes of reproduction and uneven development of countries' economies raised in the late XIX - early XX century such scientists as J. Schumpeter [1], M. Tugan-Baranovsky [2], M. Kondratiev [3]. In modern theories of scientific knowledge is considered the main resource of the economy and social sphere. This position is reflected in the works of many foreign scientists. 
The most profound findings were Massachusetts Institute of Technology Professor Robert Solow [4], Nobel laureate. In the model of economic dynamics, it developed, technological advances recognized significant factor in economic growth along with such factors as capital equipment and population growth.

Study the impact of innovation on national economic growth to explain the differences in economic dynamics between developed countries and developing countries on the work of T. Brenner [5], J. Nahe [6], J. Jimenez [7] and others.

The value and role of innovation factor in ensuring high economic growth is a subject of intense discussion among local scientists. Particularly, the question of the contribution of new technologies to the economic development of the countries covered in the writings of $\mathrm{V}$. Zakharchenko [8], with the conviction of which level of dynamism and innovation sphere - science, high-tech industries and companies worldwide markets technology - defines the boundaries between rich and poor countries creates a basis for sustainable economic growth. Academician Y. Pakhomov argues that, other different conditions greatest potential in increasing the quality of economic growth the country receives, among other dominant significance for product innovation. [9]. This thesis is leading the research L. Antoniuk, A. Poruchnik, V. Savchuk [10], which indicate that economic growth is ensured primarily technological progress and intellectualization of the basic factors of production in all sectors of the economy. According to their estimates, the proportion of new knowledge embodied in goods, technology, education, production in developed countries is 70 to $85 \%$ of GDP. However, not many developments covered in detail depending issue is economic development and innovation in some aspects of the innovation process that requires deepening research.

The article aims to evaluate the impact of innovation on economic dynamics in the context of individual factors in Europe in general and Ukraine in particular.

The basic material. Innovative processes are the driving force economic development of society, are carried out in different countries with different intensity and characteristics that makes economic power of each country and its perspectives on the global market. One of the main strategic documents that define European policy, including innovation, is the economic development strategy "Europe 2020" [11] adopted in 2010. This document defined three mutually reinforcing priorities of:

- "smart growth": growth based on knowledge and innovation;

- "sustainable growth": promoting a more efficient use of resources, the development of more environmentally friendly and competitive economy;

- "comprehensive growth": to stimulate the economy with a high level of employment, promote social and territorial cohesion.

Research and innovation proposed by the European Commission as one of the five main areas of activity that have guided European countries to achieve their goals. It is assumed that an innovative step will be a powerful catalyst for achieving high and stable economic growth, ensure the competitiveness of national economies.

Comparative analysis of innovation is based on the use of the composite index, which currently has more than a hundred. One of the most informative assessment tools of innovation in Europe is the European Innovation Scoreboard, or European scale innovation (European Innovation Scoreboard) [12]. The composite index of Innovation (SII-Summary Innovation Index), calculated on the basis of statistical data obtained from national statistical agencies or international organizations, based on 27 indicators of systematic ten blocks, "Human resources", "Attractive research systems", "Innovation-friendly environment", "Finance and support", "Firm investments", "Innovators" "Linkages", "Intellectual assets", "Employment impacts", "Economic effects".

The composite index is calculated innovation as the average for these groups. The comparison 
between the 36 countries of Europe is based on the results of the EU's activities in 2010, thus monitoring changes in time.

The rating, which is based on comparative analysis of composite index, allows determining the status of each country in terms of innovation and identifying its position in the respective group - "Innovation Leader", "Strong Innovator", "Moderate Innovator" or "Modest Innovator" (Fig. 1).

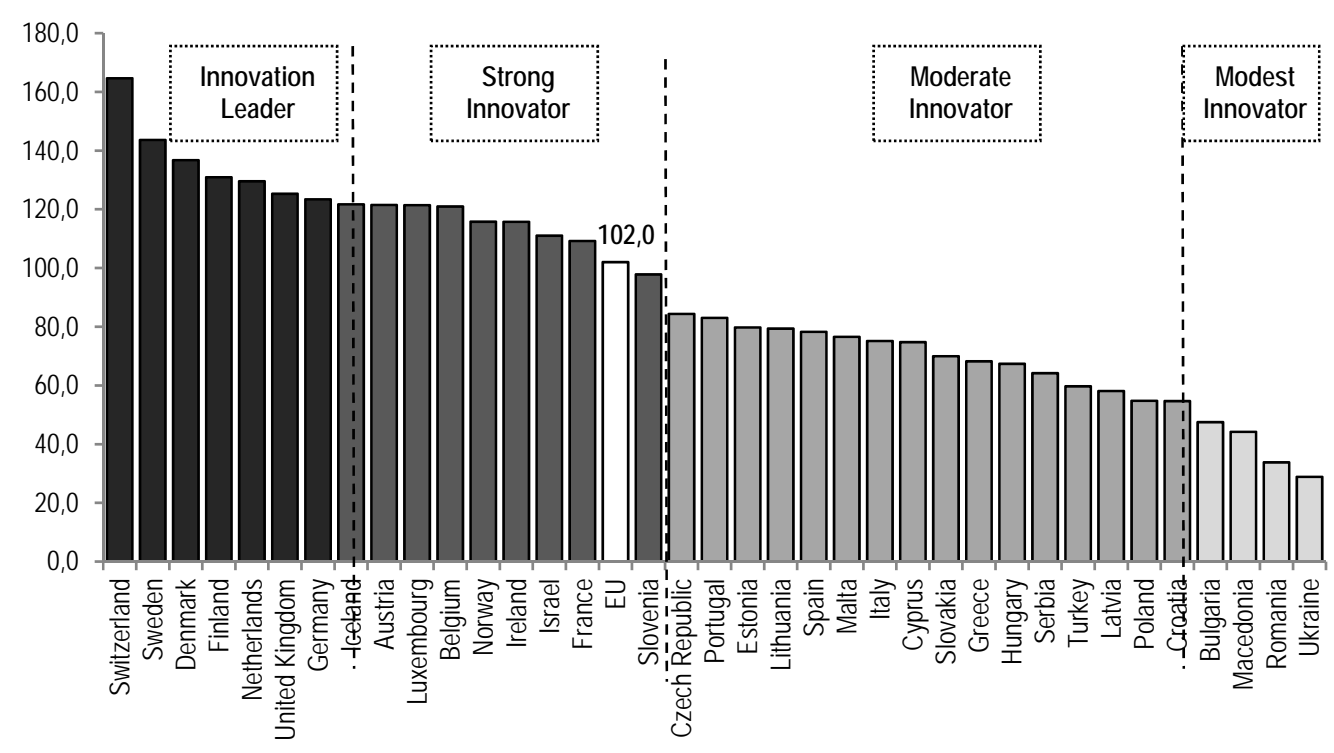

Figure 1 - Consolidated index of innovation of the countries of Europe, 2016 in comparison with the corresponding indicator of the EU in 2010 (in percent) (built according to the authors [12])

The leading countries for innovative activity and performance (Switzerland, Sweden, Denmark, Finland, Germany, the Netherlands) have a much more important indicator of innovation than the average for the sample. Ukraine occupies the lowest relative position in the above ranking and belongs to the group of countries with the status of "innovators emerging". The value of the index of growth of innovations for our country $(28,9)$ is 5,7 times lower than for the leaders of the countries, and 3,5 times than the average in the $\mathrm{EU}(102,0)$.

The study of the dynamics of innovation activity in European countries for the period from 2006 to 2010, according to the European Commission, shows the greatest progress, mainly in those countries, belonging to a group of moderate innovators (Lithuania, Serbia, Malta, Turkey, Latvia, Slovakia) (Fig. 2).

Some countries in the highest values of the indicator of innovation productivity in 2016 (Germany, Denmark, Finland) have worsened their positions over the last six years compared to 2010, with an average growth of 2,0 percentage points across the $\mathrm{EU}$.

Ranking countries on the basis of the indicator allows you to define how national economic growth based on innovation. The interdependence between economic phenomena can be detected by using different statistical methods. Widespread way to determine the closeness of connection is the calculation of Spearman's rank correlation coefficient - a measure of nonparametric statistical relationship between two variables using monotonic function. 
Л.В. Смолій, А.О. Ревуцька, І.М. Новак. Вплив інноваційного чинника на економічну динаміку в країнах Європи

Method for determining factor rating provides for the studied parameters to determine the density of communication between them. The algorithm of this analysis periodically examined by scientists [13-15], so details stop them consider inappropriate.

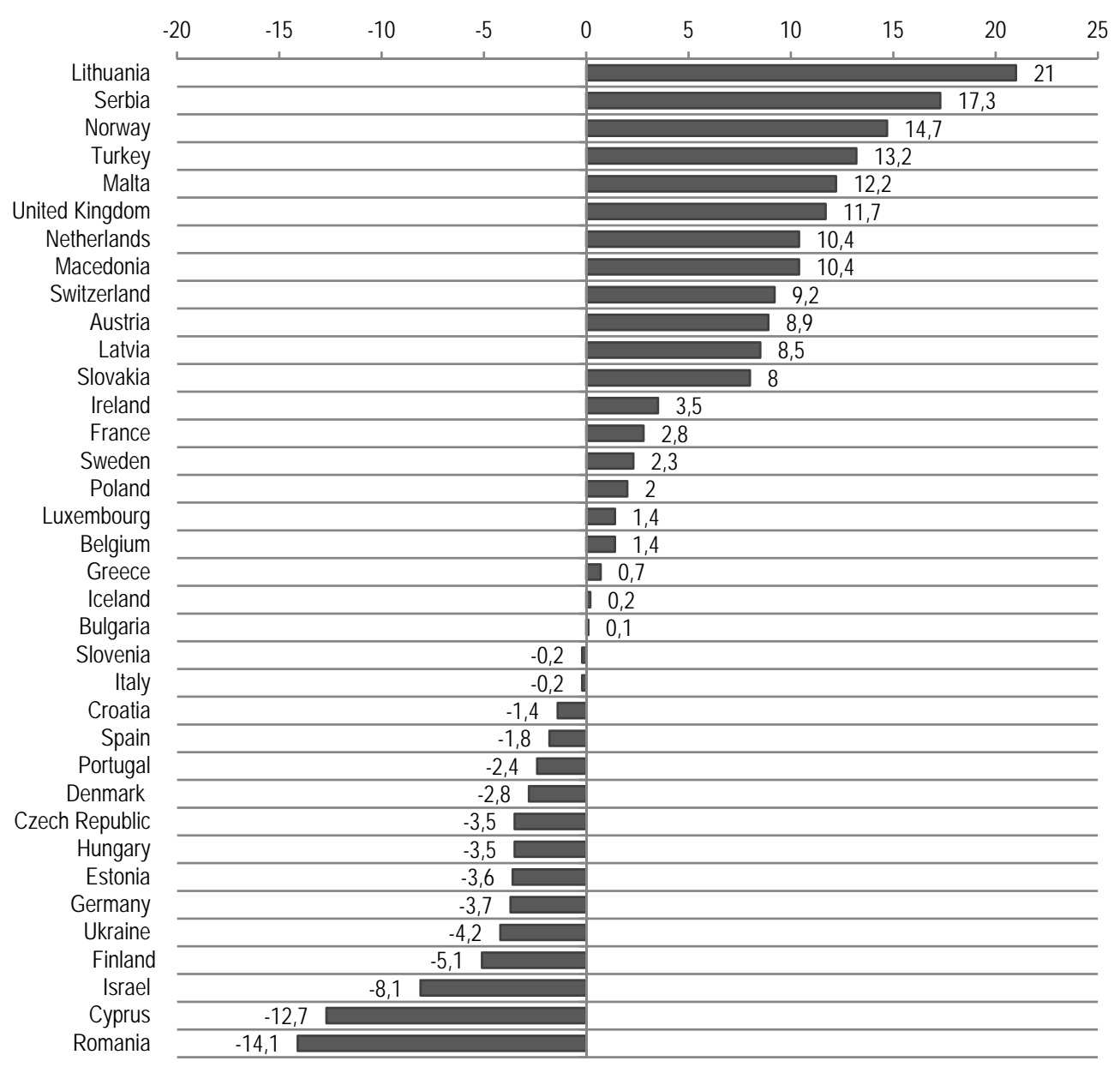

Figure 2 - Changing the relative innovation performance of European countries in 2016 compared with 2010 (percentage points) (built according to the authors [12])

To assess the relationship of innovation and economic development of individual countries we selected indicators such as the aforementioned composite index of innovation and GDP per capita at purchasing power parity (PPP) (in constant prices in 2011, expressed in US dollars) (Table 1).

The value index calculated Spearman's rank correlation is 0,899 , which confirms the high level of dependence between two variables analyzed (in 89,9 cases out of 100 GDP per capita PPP factor determined innovation economy). The test statistically significant correlation between the indicators found that the coefficient calculated rank correlation exceeds a critical value to its materiality level of 
0,01 and sample size $36(0,43)$. Consequently, the essentiality of communication with probability 0,99 proved.

Table 1 - Initial data for the calculation of rank correlation, 2016

(developed by the authors according to $[12,16]$ )

\begin{tabular}{|c|c|c|c|c|c|}
\hline \multirow{2}{*}{ 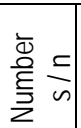 } & \multirow[b]{2}{*}{ Name of country } & \multicolumn{2}{|c|}{ The composite index of innovation } & \multicolumn{2}{|c|}{ GDP per capita PPP } \\
\hline & & coefficient & rank & USD USA & rank \\
\hline 1 & Austria & 0,599 & 9 & 50078 & 7 \\
\hline 2 & Belgium & 0,597 & 11 & 46383 & 11 \\
\hline 3 & Bulgaria & 0,234 & 33 & 19199 & 33 \\
\hline 4 & Croatia & 0,270 & 31 & 23596 & 32 \\
\hline 5 & Cyprus & 0,369 & 24 & 32580 & 21 \\
\hline 6 & Czech Republic & 0,416 & 17 & 34711 & 19 \\
\hline 7 & Denmark & 0,675 & 3 & 49696 & 8 \\
\hline 8 & Estonia & 0,393 & 19 & 29365 & 25 \\
\hline 9 & Finland & 0,646 & 4 & 43053 & 12 \\
\hline 10 & Macedonia & 0,539 & 15 & 41466 & 14 \\
\hline 11 & France & 0,609 & 7 & 48730 & 10 \\
\hline 12 & Germany & 0,337 & 26 & 26783 & 27 \\
\hline 13 & Greece & 0,332 & 27 & 26681 & 28 \\
\hline 14 & Hungary & 0,600 & 8 & 51399 & 5 \\
\hline 15 & Iceland & 0,571 & 12 & 68883 & 2 \\
\hline 16 & Ireland & 0,548 & 14 & 37901 & 16 \\
\hline 17 & Israel & 0,371 & 23 & 38161 & 15 \\
\hline 18 & Italy & 0,287 & 30 & 26031 & 29 \\
\hline 19 & Latvia & 0,391 & 20 & 29966 & 24 \\
\hline 20 & Lithuania & 0,599 & 10 & 105882 & 1 \\
\hline 21 & Luxembourg & 0,218 & 34 & 15121 & 34 \\
\hline 22 & Malta & 0,378 & 22 & 37899 & 17 \\
\hline 23 & Netherlands & 0,639 & 5 & 50898 & 6 \\
\hline 24 & Norway & 0,571 & 13 & 59302 & 4 \\
\hline 25 & Poland & 0,270 & 32 & 27811 & 26 \\
\hline 26 & Portugal & 0,409 & 18 & 30624 & 23 \\
\hline 27 & Romania & 0,167 & 35 & 23626 & 31 \\
\hline 28 & Serbia & 0,317 & 28 & 14512 & 35 \\
\hline 29 & Slovakia & 0,345 & 25 & 30632 & 22 \\
\hline 30 & Slovenia & 0,482 & 16 & 32885 & 20 \\
\hline 31 & Spain & 0,386 & 21 & 36310 & 18 \\
\hline 32 & Sweden & 0,708 & 2 & 49175 & 9 \\
\hline 33 & Switzerland & 0,812 & 1 & 62881 & 3 \\
\hline 34 & Turkey & 0,294 & 29 & 24244 & 30 \\
\hline 35 & Ukraine & 0,142 & 36 & 8272 & 36 \\
\hline 36 & United Kingdom & 0,618 & 6 & 42609 & 13 \\
\hline
\end{tabular}

The implementation of a similar statistical study according to the data for 2010-2016 also showed the existence of a high degree of tightness of communication between the analyzed indicators (Table 2). 
Л.В. Смолій, А.О. Ревуцька, І.М. Новак. Вплив інноваційного чинника на економічну динаміку в країнах Європи

Table 2 - Results of the assessment of the correlation between innovation and economic development in Europe, 2010-2016 (developed by the authors according to [12, 16])

\begin{tabular}{|l|c|c|c|c|c|c|c|}
\hline \multicolumn{1}{|c|}{ Indicator } & 2010 & 2011 & 2012 & 2013 & 2014 & 2015 & 2016 \\
\hline Spirman's rank correlation coefficient & 0,905 & 0,910 & 0,902 & 0,909 & 0,900 & 0,908 & 0,899 \\
\hline $\begin{array}{l}\text { The critical value of the coefficient of rank } \\
\text { correlation for the significance level is } 0.01\end{array}$ & 0,43 & 0,43 & 0,43 & 0,43 & 0,43 & 0,43 & 0,43 \\
\hline $\begin{array}{l}\text { Probability of the significance of } \\
\text { communication, coefficient }\end{array}$ & 0,99 & 0,99 & 0,99 & 0,99 & 0,99 & 0,99 & 0,99 \\
\hline Sample size (countries), units & 36 & 36 & 36 & 36 & 36 & 36 & 36 \\
\hline
\end{tabular}

To confirm valid results findings about the relationship between the degree of innovation and GDP per capita feasibility of grouping, which traced the said dependence (Table 3).

Table 3 - Interrelation between indicators of innovation and economic development of European countries, in 2016 (according to the authors developed [12, 16])

\begin{tabular}{|c|c|c|c|c|}
\hline $\begin{array}{c}\text { Grouped } \\
\text { sign } \\
\text { (composite } \\
\text { index of } \\
\text { innovation) }\end{array}$ & $\begin{array}{c}\text { The number of } \\
\text { countries in } \\
\text { the group, } \\
\text { unity. }\end{array}$ & Countries & $\begin{array}{c}\text { Average } \\
\text { composite } \\
\text { index } \\
\text { innovation } \\
\text { coefficient }\end{array}$ & $\begin{array}{c}\text { Average GDP } \\
\text { per capita (PPP), } \\
\text { thousand Dollars } \\
\text { USA }\end{array}$ \\
\hline $0,142-0,276$ & 6 & $\begin{array}{c}\text { Poland, Croatia, Bulgaria, Former } \\
\text { Yugoslav Republic of Macedonia, } \\
\text { Romania, Ukraine }\end{array}$ & 0,217 & 19,6 \\
\hline $0,277-0,410$ & 13 & $\begin{array}{c}\text { Portugal, Greece, Spain, Hungary, } \\
\text { Slovakia, Serbia, Italy, Cyprus, Estonia, } \\
\text { Malta, Latvia, Lithuania, Turkey, }\end{array}$ & 0,355 & 29,5 \\
\hline $0,411-0,544$ & 3 & $\begin{array}{c}\text { Slovenia, Czech Republic, France } \\
\text { United Kingdom, Germany, Iceland, } \\
\text { Austria, Luxembourg, Belgium, Ireland, } \\
\text { Israel, Norway }\end{array}$ & 0,479 & 36,4 \\
\hline $0,545-0,618$ & 9 & $\begin{array}{r}\text { Switzerland, Sweden, Denmark, } \\
\text { Finland, Netherlands }\end{array}$ & 0,696 & 56,8 \\
\hline $0,619-0,812$ & 5 & X & 0,448 & 31,1 \\
\hline Together & 36 & R & & 38,3 \\
\hline
\end{tabular}

The results of analytical grouping show that growth in the economy of innovation positively affects the volume of GDP per capita PPP. This confirms the earlier conclusion about the existence of a close link between innovation and economic development. However, the trend of positive GDP per capita dynamics in the first four groups of countries is not fulfilled for the group of countries with the highest values of the consolidated index of innovations.

This is explained that, according to many researchers, greater orientation of the innovative type of development contains, along with undeniable advantages, also a threat on the prospects of sustainability of such development. The most powerful economies, which focus on innovative type of development inherent in the phenomenon of financial "bubbles" speculative capital flows in high-tech areas, the emergence of semi-legal businesses [17]. Constant heightened threat of such manifestations, despite powerful resource potential consequences for the repayment of these phenomena gradually depletes the economy. 
An objective assessment trends in the development of national innovation systems to evaluate their strengths and weaknesses and to develop ways of improvement of organizational and economic mechanism of innovation. The approach to the assessment of the position on indicators of the European Innovation Scoreboard provides display all stages and phases of innovation and scientific and technological activities, as well as its effectiveness. This allows to detail the impact of certain factors on GDP per capita and single out the most significant ones.

One of the main means of research relationships between socio-economic variables is correlation and regression analysis, the use of which is caused by a large number of operating factors. The peculiarity of this analysis is that the change effective signs of predetermined factors influence not as a whole and in part, because it is possible influence of other factors. Assessment indicators distress communications between innovation and economic development in Europe was conducted on the basis of empirical data for 2010-2016. A different sample size for each of the ten indicator blocks is due to the inaccessibility of data for specific indicators in the context of individual countries. Multiple correlation and regression models constructed for each of these blocks. A productive variable has been selected GDP per capita (for PPP), factor factors - the relative indexes included in the system of indicators of the European innovation scoreboard are grouped according to directions. Effective selected variable GDP per capita (PPP), factor variable - relative indices that form part of the European Innovation Scoreboard indicators grouped by directions. Multiple correlation and regression models constructed for each of the eight blocks of parameters (Table 4).

Table 4 - Results of the analysis of density connection between GDP per capita (PPP) and innovation performance of European countries, 2010-2016 (developed by the authors based on [12])

\begin{tabular}{|c|c|c|c|c|}
\hline $\begin{array}{c}\text { Distress } \\
\text { communications }\end{array}$ & $\begin{array}{l}\text { Groups of } \\
\text { indicators }\end{array}$ & $\begin{array}{l}\text { Number } \\
\text { Countries } \\
\text { in the } \\
\text { sample }\end{array}$ & $\begin{array}{c}\text { Coefficient } \\
\text { Correlation } \\
\text { R }\end{array}$ & The regression equation \\
\hline Moderate & Linkages & 34 & 0,458 & $\begin{array}{c}y=29671,2+969,2 x_{1}+91,6 x_{2}- \\
-174205,0 x_{3}\end{array}$ \\
\hline \multirow{8}{*}{ Considerable } & Firm investments & 31 & 0,571 & $\begin{aligned} y=29506,9+ & 3899,9 x_{1}-15017,5 x_{2}+ \\
+ & 754,9 x_{3}\end{aligned}$ \\
\hline & $\begin{array}{l}\text { Finance and } \\
\text { Support }\end{array}$ & 34 & 0,677 & $y=17709,8-7691,7 x_{1}+4239,3 x_{2}$ \\
\hline & Human resources & 33 & 0,552 & $y=7376,9-957,3 x_{1}+520,7 x_{2}+981,0 x_{3}$ \\
\hline & Intellectual assets & 35 & 0,561 & $\begin{aligned} y=20729,4 & +1518,5 x_{1}+158,1 x_{2}+ \\
& +2564,4 x_{3}\end{aligned}$ \\
\hline & $\begin{array}{l}\text { Attractive research } \\
\text { systems }\end{array}$ & 33 & 0,606 & $y=20942,8+3,4 x_{1}+507,5 x_{2}+505,1 x_{3}$ \\
\hline & $\begin{array}{l}\text { Employment } \\
\text { impacts }\end{array}$ & 29 & 0,573 & $y=-5882,81+2950,3 x_{1}+588,5 x_{2}$ \\
\hline & Economic effect & 36 & 0,621 & $y=6900,7-10,4 x_{1}+618,7 x_{2}-298,1 x_{3}$ \\
\hline & Innovators & 35 & 0,523 & $y=8241,8+77,0 x_{1}-67,9 x_{2}+1038,6 x_{3}$ \\
\hline High & $\begin{array}{l}\text { Innovation-friendly } \\
\text { environment }\end{array}$ & 31 & 0,772 & $y=21175,3-202,3 x_{1}+5904,2 x_{2}$ \\
\hline
\end{tabular}

A high correlation coefficient for the factors that make up the block "Innovation-friendly environment" shows the close connection between the study variables, as evidenced by the correlation coefficient $(0,772)$. This group includes such indicators as the share of enterprises with access to fast broadband Internet access (\%); the prevalence of entrepreneurial activity focused on the use of innovative products (coefficient). Evaluation of reliability models made by the coefficient of determination (R2), whose value 
is obtained for these factors is 0.596 . This means that $59.6 \%$ of the variation in GDP per capita included in the conditional correlation and regression model factors and others determined the effective rate fluctuations others.

Quite high density connection between the analyzed variables observed on a group of factors "research system", including data on international scientific publications prepared by the representatives of science and business sector (database Science-Metrix (Scopus)); the percentage of publications of individual countries among the top 10\% most cited publications in the international database ScienceMetrix (Scopus) in total scientific publications; and the share of doctorates and graduate students are not from the EU in the total number of doctoral and graduate. The powerful influence of these aspects of innovation in GDP per capita is confirmed by the correlation coefficient $(0,606)$ in the model.

A considerable degree of distress communications found on a group of factors "Finance and support" ,which includes indicators of expenditure on research and development work in the public sector (\% of GDP) and venture capital (\% of GDP), and also block "Economic effect", which includes the number of employed in knowledge-intensive areas of production and services (\% of total employment in the economy); The share of medium- and high-tech products in the total volume of goods exports (\%); knowledge-intensive services exports (\% of total exports of services); the volume of sales of new to market and new products for companies (the share of innovative products,\% of turnover); Licensed and patent revenues from abroad (\% of GDP).

The value of the correlation coefficient between the productive and factor indicators is 0,677 and 0,621 , respectively. The results of the analysis showed a moderate degree of dependence between the productive variable and the innovative activity of firms in the part of the formation of communications, namely: the share of innovative small and medium enterprises cooperating with other economic entities; Public-private co-financing of R\&D expenditures (as a percentage of GDP); The number of public-private joint publications per 1 million population. The dynamics of these indicators in terms of countries determined $21 \%$ of the variation of GDP per capita.

Positioning of Ukraine as a country with the lowest level of innovation among the 36 European countries that were included in the ranking, encourages the implementation of a separate analysis. In order to identify priority areas and ways of stimulating innovation processes built correlation and regression models similar to those developed above for Europe. Indicators of density and effective communication between the factor variable are shown in Table 5 .

Calculations showed that a slight degree of impact on GDP per capita in Ukraine observed indicators for groups "Innovators", "Linkages". The ability to effectively use these factors may cause an increase in economic growth as pan illustrates an example. According to the World Economic Forum, Ukraine ranks 26 among 130 countries on the index of human capital, which is classified as a high level of development [18]. According to an index level of education of the population, our country exceeds even the average in Eastern Europe [19]. Obtained results are suggest the conclusion that the use of these and other factors which determine the innovation potential of the economy, associated with certain problems.

Significant influence on the resultant trait is observed in the part of the cost of research, development and innovation, as well as the costs of innovation, not related to research and development, that were made in the business sector (group of indicators "Investment Companies").

In addition to the above, this block includes the indicator of the share of enterprises, which carry out training of personnel in the field of information and communication technologies. However, it should be borne in mind that the characteristic feature of innovation activity is the presence of negative cash flows at the initial stages of the life cycle of innovation, and between expenditure on research and development and obtain the effect of the impact of this factor on economic development there is a gap in time. 
Table 5 - Results of the analysis of density connection between GDP per capita PPP and innovation indicators Ukraine's economy, 2010-2016, (developed by the authors based on [12])

\begin{tabular}{|c|c|c|c|}
\hline $\begin{array}{c}\text { Distress } \\
\text { communications }\end{array}$ & Group indicators & $\begin{array}{c}\text { Coefficient } \\
\text { Correlation } R\end{array}$ & The regression equation \\
\hline \multirow{2}{*}{ Weak } & Innovators & 0,055 & $\mathrm{y}=990,6-42,3 \mathrm{x}_{3}$ \\
\cline { 2 - 4 } & Linkages & 0,282 & $\mathrm{y}=8520,5+389,9 \mathrm{x}_{1}-759,5 \mathrm{x}_{2}$ \\
\hline Considerable & Firm investments & 0,581 & $\mathrm{y}=11462,6-7677,9 \mathrm{x}_{1}+180,4 \mathrm{x}_{2}$ \\
\hline \multirow{4}{*}{ High } & $\begin{array}{c}\text { Attractive research } \\
\text { systems }\end{array}$ & 0,720 & $\mathrm{y}=13002,32-13668,1 \mathrm{x}_{1}$ \\
\cline { 2 - 4 } & $\begin{array}{c}\text { Finance and } \\
\text { Support }\end{array}$ & 0,786 & $\mathrm{y}=56896,2+3127,3 \mathrm{x}_{1}-27268,4 \mathrm{x}_{2}-6603,3 \mathrm{x}_{3}$ \\
\cline { 2 - 4 } & Intellectual assets & 0,879 & $\mathrm{y}=19375,3-1,72 \mathrm{x}_{1}-184,1 \mathrm{x}_{2}-484,8 \mathrm{x}_{3}$ \\
\cline { 2 - 4 } & Economic effect & 0,854 & \\
\hline
\end{tabular}

The high degree of interconnection is determined by such factors of factors as "Research system", "Economic effect" components are listed above and "Finance and Support", which combines indicators of expenditure on research and development in the public sector (\% of GDP) and the amount of venture capital in total investment in GDP). In developed countries, public spending on research and development ranges from $2,5 \%$ to $3 \%$ of GDP, while that for the implementation of its functions science funding should not be lower than 1,7\% of GDP. In our country science funding in 2016 were carried out at the level of $0,17 \%$ of GDP [20], while the critical level below which we cannot expect to receive economic benefit of science - is $0,9 \%$ [21, p. 64]. Invocation of unused capacity in the proof of funding required to create the conditions for modernization of the national economy and its growth.

The greatest influence on the productive value amounted unit values of "Intellectual assets" a variation of GDP per capita at $72,9 \%$ determined variation factors included in this block. According to the factors included in this block of indicators, a positive dynamics is observed in our country (except for the number of applications for a trademark in the amount of 1 billion GDP (for PPP)), which provided that the trends allows to express optimism for improving Ukraine's position in the rankings innovation and economic development (Fig. 3)

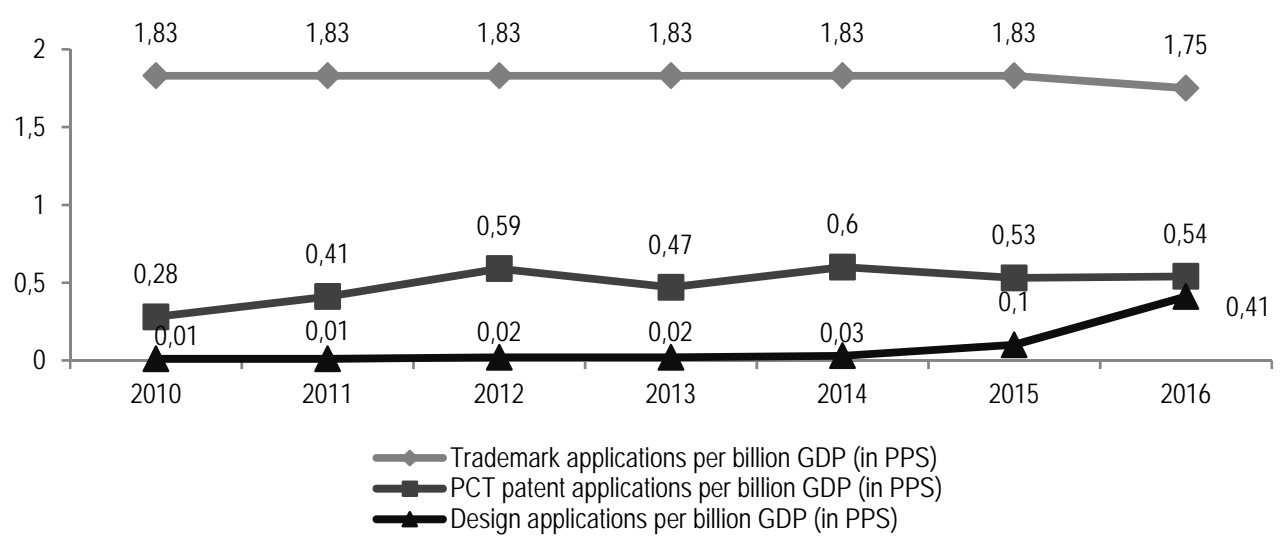

Figure 3 - The evolution of the innovation development of Ukraine, members of the group "Intellectual assets" on the methodology developed by the European Commission, 2010-2016, (authors constructed according to [12]) 
Now Ukraine faces the task more fully realize their potential with the aim of entering one of the developed countries. According to the World Economic Forum [22], formed on the basis of ranking countries in terms of economic development, Ukraine belongs to the group factor ("Primary") stage, when the sources are either raw materials or cheap unskilled labor (higher degree occupied countries included groups "effective" and "innovative" development). Features Ukrainian national innovation systems require the use of specific methods and means of influence to ensure higher rates of economic growth by enhancing innovative use of available capacity and efficiency.

Conclusions and recommendations for further research. The evaluation of the relationship indicators of innovation and economic development in Europe confirmed the hypothesis of the high dependence of these parameters. Detected trends show that the foundation to improve the economy and create conditions for ensuring competitive advantage is the implementation model innovation. Assessment for of communication between GDP per capita, economic growth and indicators of the European scale innovation in Europe by the value of the coefficient of rank correlation and grouping analytical results lead to the conclusion of a direct relationship between them. Detailing the impact of individual groups of factors on GDP per capita using correlation and regression analysis allowed single out the most significant of them, which further contribute to the development directions of improvement of organizational and economic mechanism of innovation. Found that the most significant factors influence the level of economic development of the innovation analyzed for a set of European countries is the dynamics of belonging to the group "Innovation-friendly environment". In contrast to Europe, where factors were found with low connection of performance indicators (GDP per capita in PPP terms) in Ukraine low density of such a connection was established groups of indicators blocs "Innovators" and "Linkages" and the most significant correlation between economic and innovative development observed in the group of indicators "Intellectual assets".

Research of quantitative parameters of influence the innovation factor in the level of economic development of Europe in general and Ukraine in particular, makes it possible to identify the strengths and weaknesses of the implementation of innovative processes in the region, identify untapped reserves of economic growth by improving the efficiency of innovative potential that create conditions for the reduction of the uneven development of states and formation of economy based on knowledge. Implementation of the model of economic growth by stimulating innovative changes requires the development and use of mechanisms of transformation of innovation driving force for the effective functioning of the economic system that is the subject of further deepening research problems raised.

1. Шумпетер Й. Теорія економічного розвитку. Дослідження прибутків, капіталу, кредиту, відсотка та економічного циклу / Й. Шумпетер ; пер [з англ.] В. Старка. - К. : Києво-Могилянська академія, 2012. - 242 с.

2. Туган-Барановский Н.И. Экономические очерки : монография / Н.И. Туган-Барановский; Предисл. В.В.Перской, Г.Н.Сорвиной. - М. : РОССПЭН, 1998. - 526 с.

3. Кондратьев Н.Д. Большие циклы конъюнктуры и теория предвидения / Н.Д. Кондратьев. - М. : Экономика, 2002. -766 C.

4. Solow R. Technical change and the aggregate production function / R. Solow // Rev. of Economics and statistics. - 1957.

5. Brenner Th. Science, Innovation and National Growth [electronic resource] / Th. Brenner // Annual Conference 2015 (Muenster): Economic Development - Theory and Policy, Verein für Socialpolitik / German Economic Association. - Access mode: http://EconPapers.repec.org/RePEc:zbw:vfsc15:112873.

6. Nae G. Economic Growth at Regional Level and Innovation: Is There Any Link? [electronic resource] / G. Nae, Cr. Sima // Annals of the University of Petrosani. - Economics, 13. - 2013. - Issue 1. - P. 149-156. - Access mode: http://EconPapers.repec.org/RePEc:pet:annals:v:13:y:2013:i:1:p:149-156.

7. J.R. Himenez. A non-parametric approach to innovation gaps and economic growth [electronic resource] / J.R. Perilla Himenez // Journal of Economic and Financial Studies (JEFS). - 2015. - Issue 5. - P. 63-69. - Access mode: http://EconPapers.repec.org/RePEc:Irc:lareco:v:3:y:2015:i:5:p:63-69.

8. Захарченко В.І. Інновації та економічне зростання в сучасній економіці / В.І. Захарченко ; Інноваційна економіка: теоретичні та практичні аспекти : монографрія / за ред. д.е.н., доц. Є.І. Масленнікова. - Херсон : Грінь Д.С., 2016. - 854 с. 
9. Пахомов Ю. Потрібно сформувати антикризову систему державного менеджменту / Ю. Пахомов // Урядовий кур'єр. - 20.02.2003. - С. 5-6.

10. Інновації: теорія, механізм розробки та комерціалізації : монографія / Л.Л. Антонюк, А.М. Поручник, В.С. Савчук. K. : KHEY, 2003. -394 c.

11. Europe 2020. A European strategy for smart, sustainable and inclusive growth / Europian Commission. $-2010 .-37$ p.

12. European Innovation Scoreboard 2017 [Електронний ресурс]. - Режим доступу: http://ec.europa.eu/growth/industry/innovation/facts-figures/scoreboards en.

13. Ольвінська Ю.О. Використання методу рангової кореляції при аналізі розвитку малого підприємництва / Ю.О. Ольвінська, О.В. Самотоєнкова; за ред.: М. І. Звєрякова (голов. ред.) та ін. // Вісник соціально-економічних досліджень : зб. наук. праць. - Одеса : Одеський національний економічний університет, 2015. - № 3 (58). - С. 161-169.

14. Чичуліна К.В. Кореляційний зв'язок в економіко-математичних моделях / К.В. Чичуліна // Наукові праці Полтавської державної аграрної академії. - Вип.1(4) - Т. 3. - Полтава : ПДАА. - 2012. - С. 250-255.

15. Драчук Ю.З. Оцінка обсягу капітальних інвестицій для інноваційного розвитку: регіональний аспект [Електронний ресурс] / Ю.3. Драчук, Л.О. Сав'юк, Н.В. Трушкіна // Науковий вісник Мукачівського державного університету. - 2016. Вип. 1. - С. 216-224. - Режим доступу: http://nbuv.gov.ua/UJRN/nvmdue_2016_1_38.

16. World Data Atlas [Електронний ресурc]. - Режим доступу: https://knoema.com/atlas/topics/Economy.

17. Перспективи інноваційного розвитку України (аналітична доповідь) [Електронний ресурс] // Національний інститут стратегічних досліджень, 2002. - Режим доступу: http://www.old.niss.gov.ua/Table/Zhalilo21/003.htm.

18. The Human Capital Report 2016 [Електронний ресурс]. - Режим доступу: https://www.weforum.org/reports/the-humancapital-report-2016.

19. Доповідь Програми розвитку ООН про людський розвиток «Робота задля людського розвитку» [Електронний pecypc]. - Режим доступу: http://www.nas.gov.ua/text/pdfNews/2015_Human_Development_Report.pdf.

20. Закон України «Про Державний бюджет України на 2016 рік» від 28.12.2016 р. № 928-19. [Електронний ресурс]. Режим доступу: http://zakon2.rada.gov.ua/laws/show/928-19.

21. Качинський А. Б. Індикатори національної безпеки: визначення та застосування їх граничних значень : монографія / А. Б. Качинський. - К. : НІСД, 2013. - 104 с.

22. The Global Competitiveness Report 2016-2017 [Електронний ресурс]. - Режим доступу: http://www3.weforum.org/docs/GCR2016-2017/05FullReport/TheGlobalCompetitivenessReport2016-2017_FINAL.pdf.

1. Shumpeter, J. (2012). Teoriia ekonomichnoho rozvytku. Doslidzhennia prybutkiv, kapitalu, kredytu, vidsotka ta ekonomichnoho tsyklu [Theory of Economic Development. Research income, capital, credit and economic cycle rate]. (V. Starka, Trans). Kyiv: Kyievo-Mohylianska akademiia [in Ukrainian].

2. Tuhan-Baranovskyi, N.I. (1998). Ekonomycheskye ocherky [Economic Essay]. Moscow: ROSSPEN [in Russian].

3. Kondratev, N.D. (2002). Bolshye tsykly koniunktury y teoryia predvydenyia [Large cycles of conjuncture and theory of foresight]. Moscow: Economica [in Russian].

4. Solow, R. (1957). Technical change and the aggregate production function. Rev. of Economics and statistics [in English].

5. Brenner, Th. (2015). Science, Innovation and National Growth. Annual Conference 2015 (Muenster): Economic Development - Theory and Policy, Verein für Socialpolitik. German Economic Association. Retrieved from http://EconPapers.repec.org/RePEc:zbw:vfsc15:112873 [in English].

6. Nae, G., \& Sima, Cr. (2013). Economic Growth at Regional Level and Innovation: Is There Any Link?. Annals of the University of Petrosani. Economics, 13, (Issue 1), 149-156. Retrieved from: http://EconPapers.repec.org/RePEc:pet:annals:v:13:y:2013:i:1:p:149-156 [in English].

7. Himenez, J. R. (2015). A non-parametric approach to innovation gaps and economic growth. Journal of Economic and Financial Studies (JEFS), 5, 63-69. Retrieved from http://EconPapers.repec.org/RePEc:Irc:lareco:v:3:y:2015:i:5:p:63-69.

8. Zakharchenko, V.I. (2016). Innovatsii ta ekonomichne zrostannia v suchasnii ekonomitsi [Innovation and growth in today's economy]. Innovatsiina ekonomika: teoretychni ta praktychni aspekty - Innovative Economy: Theoretical and Practical Aspects. Ye.I. Maslennikova (Ed.). Kherson: Hrin D.S. [in Ukrainian].

9. Pakhomov, Yu. (2003). Potribno sformuvaty antykryzovu systemu derzhavnoho menedzhmentu [Necessary to form a crisis management system of state management]. Uriadovyi kurier - Governmental courier, 5-6 [in Ukrainian].

10. Antoniuk, L.L., Poruchnyk, A.M., \& Savchuk, V.S. (2003). Innovatsii: teoriia, mekhanizm rozrobky ta komertsializatsii [Innovations: theory, mechanism of development and commercialization]. Kyiv: KNEU [in Ukrainian].

11. Europe 2020. A European strategy for smart, sustainable and inclusive growth. (2010). Europian Commission [in English].

12. European Innovation Scoreboard 2017. (n.d.). ec.europa.eu. Retrieved from http://ec.europa.eu/growth/industry/innovation/facts-figures/scoreboards_en [in English].

13. Olvinska, Yu, \& Samotoienkova, O.V. (2015). Vykorystannia metodu ranhovoi koreliatsii pry analizi rozvytku maloho pidpryiemnytstva [Using rank correlation in the analysis of small business development]. M.I. Zvieriakova (Eds.) Visnyk sotsialnoekonomichnykh doslidzhen - Journal of Social and Economic Research, 3(58), 161-169 [in Ukrainian].

14. Chychulina, K.V. (2012). Koreliatsiinyi zviazok v ekonomiko-matematychnykh modeliakh [Correlation in economic and 
mathematical models]. Naukovi pratsi Poltavskoi derzhavnoi ahrarnoi akademii - Proceedings of Poltava State Agrarian Academy. 1(14), (Vol. 3), 250-255 [in Ukrainian].

15. Drachuk, Yu.Z., Saviuk, L.O., \& Trushkina, N.V. (2016). Otsinka obsiahu kapitalnykh investytsii dlia innovatsiinoho rozvytku: rehionalnyi aspect [Estimation of capital investments for innovative development: a regional perspective]. Naukovyi visnyk Mukachivskoho derzhavnoho universytetu - Scientific Journal of Mukachevo State University, 1. Retrieved from http://nbuv.gov.ua/UJRN/nvmdue_2016_138 [in Ukrainian].

16. World Data Atlas. (n.d.). https://knoema.com. Retrieved from: https://knoema.com/atlas/topics/Economy [in English].

17. Perspektyvy innovatsiinoho rozvytku Ukrainy (analitychna dopovid) [Prospects for Innovation Development of Ukraine (Analytical Report)]. (n.d.). old.niss.gov.ua. Retrieved from: http://www.old.niss.gov.ua/Table/Zhalilo21/003.htm [in Ukrainian].

18. The Human Capital Report 2016. (n.d.). www.weforum.org. Retrieved from: https://www.weforum.org/reports/the-humancapital-report-2016 [in English].

19. Dopovid Prohramy rozvytku OON pro liudskyi rozvytok "Robota zadlia liudskoho rozvytku" [Report of the UNDP Human Development "Working for human development"]. (n.d.). nas.gov.ua. Retrieved from http://www.nas.gov.ua/text/pdfNews/2015_Human_Development_Report.pdf [in Ukrainian].

20. Zakon Ukrainy "Pro Derzhavnyi biudzhet Ukrainy na 2016 rik" [The Law of Ukraine «On the State Budget of Ukraine for 2016»]. (n.d.). zakon2.rada.gov.ua. Retrieved from http://zakon2.rada.gov.ua/laws/show/928-19 [in Ukrainian].

21. Kachynskyi, A.B. (2013). Indykatory natsionalnoi bezpeky: vyznachennia ta zastosuvannia yikh hranychnykh znachen [Indicators of National Security: definition and application of limit values]. Kyiv: NISD [in Ukrainian].

22. The Global Competitiveness Report 2016-2017. (n.d.). www3.weforum.org. Retrieved from http://www3.weforum.org/docs/GCR2016-2017/05FullReport/TheGlobalCompetitivenessReport2016-2017_FINAL.pdf [in English].

Л.В. Смолій, канд. екон. наук, доцент кафедри економіки, Уманський національний університет садівництва (м. Умань, Україна);

A.О. Ревуцька, канд. екон. наук, ст. викладач кафедри економіки, Уманський національний університет садівництва (м. Умань, Україна);

I.M. Новак, канд. екон. наук, доцент кафедри менеджменту, Уманський національний університет садівництва (м. Умань, Україна)

Вплив інноваційного чинника на економічну динаміку в країнах $€_{\text {вропи }}$

В статті здійснено оцінку взаємозв'язку індикаторів рівня інноваційного та економічного розвитку у країнах Європи. Виявлено високий рівень залежності між індексом інноваційного розвитку та показником ВВП на душу населення (за ПКС). Встановлено найбільш вагомі чинники впливу на рівень економічного розвитку в частині інноваційної діяльності для сукупності аналізованих європейських країн загалом та України зокрема.

Ключові слова: інновації, інноваційний розвиток, економічне зростання, країни Європи, рейтинг, кореляційний зв'язок.

Л.В. Смолий, канд. экон. наук, доцент кафедры экономики, Уманский национальный университет садоводства (г. Умань, Украина);

А.А. Ревуцкая, канд. экон. наук, ст. преподаватель кафеедры экономики, Уманский национальный университет садоводства (г. Умань, Украина);

И.Н. Новак, канд. экон. наук, доцент кафедры менеджмента, Уманский национальный университет садоводства (г. Умань, Украина)

Влияние инновационного фактора на экономическую динамику в странах Европы

В статье осуществлена оценка взаимосвязи индикаторов уровня инновационного и экономического развития в странах Европы. Выявлен высокий уровень зависимости между индексом инновационного развития и показателем ВВП на душу населения (по ППС). Установлены наиболее значимые факторы влияния на уровень экономического развития в контексте инновационной деятельности для совокупности анализируемых европейских стран в иелом и Украины в частности.

Ключевые слова: инновации, инновационное развитие, экономический рост, страны Европы, рейтинг, корелляционная связь. 